\title{
W. R. Streitberger. The Masters of the Revels and Elizabeth I's Court The- atre. Oxford: Oxford University Press, 2016. Pp xv, 319.
}

\section{CURTIS PERRY}

University of Illinois at Urbana-Champaign

E.K. Chambers's famous, four-volume study of The Elizabethan Stage is one of the books that has shaped our received wisdom concerning early modern drama as a set of institutions and practices. But for scholars of my generation - and especially for those, like me, who write about plays but are not primarily historians of theatre - its precise shaping influence upon disciplinary commonsense may no longer be obvious. I read Chambers in graduate school, and have subsequently consulted him on occasion, but I would not be able to produce off the top of my head a list of the things I think I know about Elizabethan drama that originated with The Elizabethan Stage. One of the great pleasures of W.R. Streitberger's meticulously researched historical study of the Elizabethan masters of the revels is that it simultaneously makes aspects of our field's debt to Chambers visible and subjects many of the verities received from him to rigorous, revisionary scrutiny. In particular, as Streitberger shows, Chambers's understanding of the role of the revels office and its relationship to the flourishing of commercial theatre in Elizabethan London was distorted by a teleological idea of social evolution in which 'the mimetic instinct, deep rooted in the psychology of the folk' finds its way, with a nudge from a centralizing and bureaucratizing Tudor court, towards its 'ultimate entrenchment of economic independence.' ${ }^{1}$

The Masters of the Revels and Elizabeth I's Court Theatre offers, instead, a history of the Elizabethan Revels Office and its relation to commercial drama based upon an idea of the court as a dynamic institutional amalgam that develops in an ad hoc manner to cope with changing circumstances: the office of the master of the revels, which had been created as part the Henrician privy chamber, had to be reimagined under Elizabeth, whose privy chamber of course was staffed by women. Never a sinecure, the mastership of the revels thereafter required managerial and dramaturgical abilities as well as the savoir faire, elite social status, and patronage connections that would previously have been automatic for a gentleman of the privy chamber under Henry VIII. So, Streitberger argues, Edmund Tilney was chosen for the mastership in 1578 over Thomas Blagrave (a key figure in the mid-Elizabethan reorganization of the revels office, and one who had been who had been producing the revels with the earl of Sussex since 1573) because 
the latter — for all his valuable experience — lacked the social stature to function effectively as a courtier or as a manager of the court's self-presentation.

The early Elizabethan masters of the revels - Sir Thomas Cawarden (who had been appointed by Henry VIII and who died in 1559) and Sir Thomas Benger - were responsible for devising festive entertainments for the court. This responsibility entailed everything from writing pageant scripts to what we might call producing: overseeing things like staging, costumes, and sets. Benger, who served as master from 1559-1572, 'devised as many as sixty masks, produced over thirty plays by boy companies and close to a dozen by professional players, as well as occasional gifts offered to the queen by the Inns of Court and others' (86). Streitberger - whose book is an institutional history of the revels office organized around the biographies of its masters - takes pains to credit Benger for the thematic variety of his shows, for his innovative use of schoolboy companies, and for his 'penchant for spectacular showmanship' (89). But the revels office under Benger was also enormously costly, and his death in 1572 became an opportunity for the privy council to review the office's operation and to try to set it, henceforward, on a more affordable footing. To cut production costs, the revels office now began to make increased, regular use of plays by professional companies. Though no concrete documentary evidence links this change in the orientation of the revels to the dramatic increase in available commercial theatre spaces in and around London in the mid-1570s, Streitberger argues that the expansion of London's commercial theatre must have been spurred by 'the outsourcing of the production of plays to privileged companies' (135).

In Chambers's evolutionary narrative, commercial theatre is initially enabled by the needs of the court but then tends naturally towards economic independence. Streitberger offers, instead, a story of further outsourcing and one that emphasizes the ongoing collaboration between the revels office and those theatrical companies called upon to produce plays for the court. Rather than thinking of the creation of the Queen's Men in terms of court factionalism or as a vehicle for Tudor propaganda, Streitberger sees the company's creation as part of an ongoing effort to maintain quality and save money by regularizing the outsourcing of the revels. But while this arrangement ensured court access to theatrical talent and a repertory of plays, court performances by the Queen's Men still required significant outlay for suitable costumes and props. The companies drawn upon for court performances after the dissolution of the Queen's Men were not primarily touring companies, and so they were able to accumulate their own impressive collections of costumes and props, which reduced the costs of staging plays at court still further. Between 1558 and 1572 the Exchequer paid 
the revels office an average of $£ 659$ per season; from 1593 to 1602 the average seasonal expenditure was $£ 74$ (199).

Streitberger's narrative about cost-cutting and outsourcing is grounded primarily upon his meticulous reconstruction of the revels office and its shifting agendas, and he thus pays relatively little attention to the point of view of the commercial theatre companies brought to court by the master of the revels. Scholars interested primarily in commercial theatre may wish for more here about how commercial companies - like the Admiral's Men or the Lord Chamberlain's Men, who between them were the sole companies to perform at court between December 1594 and Shrove Tuesday 1600 - understood this arrangement in relation to their regular day-to-day operations. Though it is stuffed with arguments that will be suggestive for scholars focusing on the growth of theatre in Elizabethan London, this is ultimately a book about the revels office and its masters and not in any way a comprehensive effort to rethink the relationship between the court and commercial drama. In a thoughtful afterword, however, Streitberger does reconsider the familiar idea that Tilney regulated commercial drama in London, and he argues that this aspect of the mastership of the revels may hitherto have been misunderstood. Tilney did license plays, of course, but no evidence suggests that he had any role in regulating commercial theatre beyond London and some evidence that his regulatory role even in London may not have extended as far as many scholars assume: other authorities, including the privy council itself, tend to step in to adjudicate whenever there is serious conflicts about the content of plays. Instead, Streitberger argues that we should see Tilney's expanded authority not as primarily regulatory but rather as caretaking for the interests of the revels office: he was 'expected to work with playhouse owners, playwrights, and players to maintain a viable commercial theatre industry that remained within the bounds of tolerance' (236).

I have touched only lightly here on the book's biographical aspect. Each chapter is organized around the life of one of the Elizabethan masters of the revels, though Tilney gets two chapters and there is also a chapter focusing on the period after the death of Benger when the position remained unfilled. Each chapter contains, in addition to richly detailed institutional history a biographical account of the master in question. These sections - which are as meticulously researched as the rest of the book - extend Streitberger's argument about the way the position of master of the revels was understood as a court appointment, but readers who come to this book for insights about Elizabethan drama may find the biographical focus obtrusive at times. Still, this is a fascinating 
and impressive book, and one that will be of considerable interest for scholars of Elizabethan drama.

\section{Notes}

1 E.K. Chambers, The Elizabethan Stage, 4 vols (Oxford, 1923), 1.3. 